



\section{VICENTE MAROTTA RANGEL}

(1982-1986)

Nasceu, em São Paulo, a 14 de março de 1924.

Fez os seus primeiros estudos no Liceu Rio Branco, cursando posteriormente o Colégio Universitário da Universidade de São Paulo. Em 1942 ingressou na Faculdade de Direito de São Paulo, bacharelando-se em 1946.

Em 1948, transfere-se para a França, cursando o Institut des Hautes Études Internationales e a École des Sciences Politiques da Universidade de Paris, vindo a doutorar-se em Direito em 1949.

Retornando ao Brasil, em 1954, conquista a livre-docência de Direito Internacional Público nesta Faculdade, sendo aprovado no concurso para a cátedra, em 1967, também em Direito Internacional Público.

Lecionou, ainda, Direito Internacional Público e Direito Internacional Privado na Universidade Mackenzie, de 1967 a 1973, Ciências Políticas na Universidade Católica e Relações Internacionais na Escola de Sociologia e Política de São Paulo, de 1965 a 1973. No período de 1972-1973 esteve como Visiting Scholar na Columbia University, EUA.

Chefiou o Departamento de Direito Internacional desta Faculdade, de 1970 a 1974 e de 1978 a 1982, tendo coordenado os cursos de pós-graduação de 1974 a 1976. Foi vice-diretor da Escola de Comunicações e Artes da Universidade de São Paulo, de 1976 a 1977, e diretor desta Faculdade de Direito, de 1982 a 1986. Foi consultor jurídico do Ministério das Relações Exteriores, de agosto de 1990 a fevereiro de 1993.

É membro da Corte de Arbitragem de Haia, por decreto do presidente da República, a partir de abril de 1979, do Instituto Hispano-LusoAmericano de Direito Internacional, da Sociedade Brasileira de Direito Internacional, do Instituto Interamericano de Estudos Jurídicos Internacionais, da American Society of International Law, da International Law Association, da Société Française de Droit International, do Institut de Droit International e da Société Belge de Droit International.

Tem participado de inúmeros congressos e conferências no Brasil e no exterior, além de possuir vários artigos publicados em revistas especializadas. 


\section{Obras Publicadas}

Le fédéralisme américain à la Conférence de Bogotá. Université de Paris, 1950 (thèse).

Do conflito entre a Carta das Nações Unidas e os demais acordos internacionais.

São Paulo : Saraiva. 1954. Tese (livre-docente) Faculdade de Direito da Universidade de São Paulo.

Os conflitos entre o direito interno $e$ os tratados internacionais. V Congresso Hispano-Americano de Direito Internacional, Caracas-Mérida, 1967.

Natureza jurídica e delimitação do mar territorial. São Paulo : Revista dos Tribunais, 1970.

Brazil: arbitration. Yearbook Commercial Arbitration, Deventer, v. 14, 1989.

Public international law: the last five decades. In: A panorama of Brazilian law.

Jacob Dollinger, Keith S. Rosemm. Miami : University of Miami, 1992. p. 287-308.

Sobre la efictividad de la justicia en relaciones internacionales. S.l.p., s.c.p., 1993.

$\mathrm{O}$ direito do mar e sua unificação legislativa entre países de língua portuguesa.

Boletim da Faculdade de Direito de Coimbra, Coimbra, p. 3-23, 1985 (n. especial em homenagem ao prof. doutor Antonio de Arruda Ferrer Correia.

O Brasil e o processo decisório em direito do mar: 1964-1990. S.l.p., s.c.p., 1993.

Do homem à humanidade: o elemento fático e o direito internacional público.

In: Direito, Política, Filosofia, Poesia: estudos em homenagem ao prof. Miguel Reale no seu octogésimo aniversário. Coord. Celso Lafer, Tércio Sampaio Ferraz Júnior. São Paulo : Saraiva, 1992. p. 403-411.

Natureza jurídica e delimitação do mar territorial na Convenção das Nações Unidas sobre direito do mar. In: Temas de derecho internacional en homenaje a Frida M. Pfirter de Armas Barea. Ed. Raúl E. Vinuesa. Buenos Aires : Fundación de El Centro de Estudios Internacionales, 1989. p. 127-137.

Nova ordem internacional: fundos oceânicos e solução de controvérsias no direito do mar. In: $O$ direito na década de 90: novos aspectos: estudos em homenagem ao prof. Arnoldo Wald. Coord. Paulo Dourado de Gusmão e Semy Glanz. São Paulo : Revista dos Tribunais, 1992. p. 265-383.

Restrições ao ingresso de brasileiros em Portugal: parecer. S.l.p., s.c.p., 1993. 
Solução pacífica de controvérsias no Mercosul: estudo preliminar. S.l.p., s.c.p., 1993. 